\section{Uptake of Chylomicron Lipid by Rat Liver Parenchymal Cells in vivo}

THere are two theories about the uptake of chylomicron triglyceride by the liver. The widely held view that chylomicrons are removed intact from the circulation ${ }^{1-3}$ has been challenged by Felts and Mayes. They propose that the triglycerides are not taken up directly by the liver but are hydrolysed elsewhere by lipoprotein lipase, the resulting non-esterified fatty acids (NEFA) being taken up by the liver cells. In vivo evidence that intact chylomicrons are removed by the liver has been presented earlier $^{5}$ but was open to two objections ${ }^{4,6}$. First, heparin was used as an anticoagulant in the collection of the chylomicrons and sufficient could have remained after washing to stimulate lipoprotein lipase activity in the circulation. Second, studies on whole liver tissue may not give a true picture of events occurring in the parenchymal cells themselves, since trapping of chylomicrons in the tissue spaces does occur both in vivo and in perfusion experiments ${ }^{6}$.

To overcome both objections, the following experiments were performed. Chylomicrons were obtained after administration of glycerol tri $\left[1{ }^{14} \mathrm{C}\right]$ palmitate to rats in which thoracic duct cannulae had been established. The only heparin employed was a small amount in the saline filling the cannula when it was inserted. The first millilitre of lymph to emerge was discarded. The washed chylomicrons $(0 \cdot 75-2 \cdot 05 \mathrm{mg}$ of lipid) were injected into the exposed femoral vein of fed rats over a $30 \mathrm{sec}$ period. One minute after injection was completed, the liver was perfused with ice-cold, calcium free Locke's solution containing 0.27 molar sodium citrate, and homogenized in Hanks solution. The homogenate was filtered through nylon mesh $(60 \mu$ pore size) and the filtrate centrifuged at $1,300 \mathrm{~g}$ for $1 \mathrm{~min}$. The sedimented parenchymal cells were washed and the total lipid extracted for determination of ${ }^{14} \mathrm{C}$ distribution ${ }^{5}$.

Most of the ${ }^{14} \mathrm{C}$-palmitic acid associated with the hepatic parenchymal cells is in the triglyceride, with much smaller amounts present in the phospholipids (Table 1). Thus although studies of total quantity of lipid taken up by the liver may not be valid if based on measurements of the whole tissue, the distribution of chylomicron lipid in the parenchymal cells is very similar to that in the whole tissue ${ }^{3,5}$. When tritiated palmitic acid was injected as a complex with albumin, 57.8 per cent of the radioactivity was in the phospholipids and 27.8 per cent in the triglyceride. These measurements were made on the whole perfused liver, since the distribution of the isotope shows that there is no problem of contamination by trapped fatty acid. If chylomicron triglyceride had been hydrolysed to NEFA before uptake by the liver cells, the distribution of radioactivity should have been similar in the two experiments. As they are so different, they confirm earlier findings ${ }^{2,5,8}$ and establish that under normal physiological conditions chylomicron triglycerides are directly removed from the circulation by the liver cells.

Further evidence which counts against lipoprotein lipase filling an important role in the uptake of chylomicron lipids is given by the finding that, after inhibition of this enzyme with protamine sulphate, the pattern of uptake and metabolism of chylomicron lipids in liver is essentially the same as that seen when no inhibitor is used (compare refs. 3 and 5 ).

Table 1. DISTRIBUtion OF ${ }^{14} \mathrm{C}$ IN RAT LIVER PARENCHYMAL CELL LIPIDS 1 MIN AFTER INJECTION OF CHYLOMICRONS LABELLED WITH ${ }^{14} \mathrm{C}$ PALMITIC AOID

\begin{tabular}{|c|c|c|}
\hline \multirow[b]{2}{*}{ Lipid class } & \multicolumn{2}{|c|}{${ }^{14} \mathrm{C}$ distribution* in } \\
\hline & $\begin{array}{c}\text { Original } \\
\text { chylomicrons }\end{array}$ & $\begin{array}{l}\text { Liver cells after } \\
\text { ehylomicron injections } \dagger\end{array}$ \\
\hline Triglycerides & $93 \cdot 1$ & $73 \cdot 1 \pm 2 \cdot 4$ \\
\hline Phospholipids & 6.8 & $19 \cdot 2 \pm 3 \cdot 0$ \\
\hline Cholesterol esters & 0.4 & $1.2 \pm 0.4$ \\
\hline NEFA & $1 \cdot 1$ & $5 \cdot 3 \pm 1 \cdot 1$ \\
\hline
\end{tabular}

The failure of Felts and Mayes ${ }^{4}$ to detect significant uptake of chylomicron lipids by perfused rat liver in the absence of lipoprotein lipase is difficult to explain. Their conclusion, however, that NEFA are the principal form in which fatty acids actually traverse the liver cell membic ne is in agreement with our earlier findings ${ }^{5}$.

We are indebted to Dr J. E. French, Sir William Dunn School of Pathology, University of Oxford, for instruction in the technique of thoracic duct cannulation. This work was supported by grants from the Science Research Council and the US Public Health Service.

\section{JOAN A. Higgins}

Department of Biochemistry,

\section{Green}

University of Liverpool.

Received October 31, 1966.

${ }^{1}$ Morris, B., and French, J. E., Quart. J. Exp. Physiol., 43, 180 (1958).

${ }^{2}$ Stein, Y., and Shapiro, B., J. Lipid Res., 1, 326 (1960).

${ }^{3}$ Olivecrona, T., and Belfrage, P., Biochim. Biophys. Acta, 98, 81 (1965).

${ }^{4}$ Felts, J. M., and Mayes, P. A., Nature, 206, 195 (1965).

${ }^{5}$ Higgins, J. A., and Green, C., Biochem. J., 99, 631 (1966).

6 Felts, J. M., Ann. N.Y. Acad. Sci., 131, 24 (1965).

"Green, C., and Webb, J. A., Biochim. Biophys. Acta, 84, 404 (1964).

${ }^{3}$ Göransson, G., and Olivecrona, T., Acta Physiol. Scand., 62, 224 (1964).

\section{Freeze-drying and Protein Denaturation in Muscle Tissue; Losses in Protein Solubility}

In the course of a search for possible relationships between the freeze-drying procedure and the subsequent extractability of proteins from the freeze-dried tissue, it was found that freeze-drying of ox muscle does not necessarily reduce the extractability of the component proteins separable by Helander's procedure ${ }^{1}$ which employs, in sequence, 0.03 molar phosphate buffer and 1.1 molar potassium iodide. These findings were, in part, a confirmation of the work of Cole and Smithies ${ }^{2}$ and of Connell ${ }^{3}$ and support the thesis that freeze-drying need not cause irreversible denaturation of the proteins present. Furthermore, our results explain the observations of those workers who, in experiments in which the effects of dehydration and of high temperature were combined, found that rapid freeze-drying lowers the extractability of proteins ${ }^{4}$. Thinking that the losses in extractability reported might be caused by the high temperature generally used to accelerate freeze-drying, we tried to separate the effects of freeze-drying from those of high temperature. We were thus able to show that heat applied during the course of freeze-drying to accelerate dehydration may induce insolubility in the portion already dried, while the part still to be dried remains undamaged.

Tissue samples were cut from the longissimus dorsi taken from beef carcasses, 2 to 4 days after death. Two freezing rates were employed: (1) slices of tissue $1 \mathrm{~mm}$ thick were immersed abruptly in well stirred isopentane maintained at $-150^{\circ} \mathrm{C}$; (2) a piece of tissue roughly 2.5 $\mathrm{cm}$ thick was allowed to freeze in the still air of a cold room at $-10^{\circ} \mathrm{C}$ (these pieces were subsequently cut into cubes $1 \mathrm{~cm}$ on edge for freeze-drying).

Freeze-drying was carried out in an all-glass high vacuum apparatus ${ }^{5}$ in which the specimen chamber could be (1) maintained at any desired temperature and (2) isolated from the condenser by closure of a widebore stopcock. In all cases we maintained the specimen chamber at $-10^{\circ} \mathrm{C}$ with the aid of an automatically regulated external cooling bath, to the point where either (1) the specimen contained about 2 per cent residual moisture (on a dry weight basis) or (2) contained less than 0.2 per cent moisture, these arbitrary points of "completion" being measured by the method of increase of water vapour pressure to equilibrium (with the sample still at $\left.-10^{\circ} \mathrm{C}\right)$.

After some of the freeze-drying runs, the dried tissues were allowed to warm to room temperature, air was admitted to the apparatus, and the tissues were immedi- 